\title{
PENERAPAN METODE REGRESI LINEAR DALAM MEMPREDIKSI DATA PENJUALAN BARANG DI TOKO BANGUNAN VITA VIYA
}

\author{
${ }^{1}$ Reno Supardi \\ ${ }^{1}$ Dosen Tetap Program Studi Informatika Fakultas Ilmu Komputer Universitas Dehasen Bengkulu \\ Jl. Meranti Raya No. 32 Kota Bengkulu 38228 Telp. (0736) 22027, 26957 Fax. (0736) 341139 \\ e-mail: ociputri29@gmail.com)
}

\begin{abstract}
Vita Viya lumberyard is one of the lumberyard is located on Semangka Street, Bengkulu city. During this time the processing sales data of goods in lumberyard is still done conventionally, namely using sales notes that occur every day. Then, the note data will be made into bookkeeping to find out how many sales of goods occur every month. Management of inventory also only sees the remaining items available in the lumberyard without looking at the sales of the item. The problem that often occurs in Vita Viya lumberyard is the management of inventory, where the building materials have a usage period so that they are not suitable for sale. The application in predicting sales data of goods in Vita Viya lumberyard was made by using the Visual Basic.Net programming language by applying the linear regression method. With the construction of the application can be used as an alternative in predicting the sales data of goods in the following month based on sales data that occurred in the last 2 years starting from January 2017 to December 2018. The 2-year data will be used as a data trend to determine the predicted value of goods sold at 1 year in the future. Based on the testing that has been done, it can be concluded that the application is able to predict the sale of goods for the next 1 year based on sales data that has been inputted previously. Based on the testing of error values using the MAPE and MSE methods, it was found that the error value of the predicted value obtained from the linear regression method used the MAPE method of 0.1244575. While, the result by using the MSE method of 14.25 .
\end{abstract}

Keywords: Linear Regression Method, Prediction of Vita Viya lumberyard.

Toko Bangunan Vita Viya merupakan salah satu Toko Bangunan yang terletak di Jalan Semangka Kota Bengkulu. Selama ini proses pengolahan data penjualan barang di Toko tersebut masih dilakukan secara konvensional yaitu menggunakan nota penjualan yang terjadi setiap harinya. Data nota tersebut kemudian akan dibuat pembukuan untuk mengetahui berapa banyak penjualan barang yang terjadi setiap bulannya. Pengelolaan persediaan barang juga hanya melihat sisa barang yang tersedia di Toko tanpa melihat penjualan dari barang tersebut. Permasalahan yang sering terjadi di Toko Bangunan Vita Viya yaitu pengelolaan stok barang, di mana bahan-bahan bangunan tersebut terdapat masa pemakaian sehingga tidak layak untuk dijual. Aplikasi dalam memprediksi data penjualan barang di Toko Bangunan Vita Viya dibuat menggunakan bahasa pemrograman Visual Basic .Net dengan menerapkan metode regresi linear. Dengan dibangunnya aplikasi dapat dijadikan sebagai alternatif dalam memprediksi data penjualan barang pada bulan berikutnya berdasarkan data penjualan yang terjadi 2 tahun terakhir yaitu dimulai dari bulan Januari 2017 sampai dengan Desember 2018. Data 2 tahun tersebut akan digunakan sebagai trend data untuk mengetahui nilai prediksi penjualan barang pada 1 tahun ke depannya. Berdasarkan pengujian yang telah dilakukan, dapat ditarik kesimpulan bahwa Aplikasi mampu memprediksi penjualan barang untuk 1 tahun ke depan berdasarkan data penjualan yang telah diinputkan sebelumnya. Berdasarkan pengujian nilai error menggunakan metode MAPE dan MSE, didapatkan hasil bahwa nilai error dari hasil nilai prediksi yang didapatkan dari metode regresi linear menggunakan metode MAPE sebesar 0,1244575. Sedangkan menggunakan metode MSE sebesar 14,25.

Kata Kunci : $\quad$ Metode Regresi Linear, Prediksi Penjualan Barangm Toko Bangunan Vita Viya

\section{PENDAhUluaN}

Perkembangan dunia usaha di Indonesia mengalami persaingan cukup ketat di segala bidang, baik dalam bidang penjualan maupun jasa. Pada umumnya perusahaan mempunyai tiga tujuan dalam penjualan barang yaitu mencapai volume penjualan, mendapatkan laba tertentu, dan menunjukkan pertumbuhan perusahaan, agar tujuan tersebut dapat tercapai perusahaan mengandalkan kegiatannya dalam bentuk penjualan, untuk mengetahui volume penjualan maka diperlukan suatu prediksi (forecasting).

Penjualan merupakan suatu kegiatan yang berhubungan dengan keputusan-keputusan yang harus dibuat untuk menentukan produk dan pasarannya, penentuan struktur harga, dan pelaksanaan promosi serta pelaksanaan distribusi yang pada akhirnya akan memberikan kepuasan pada konsumen.

Prediksi atau peramalan adalah proses untuk memperkirakan berapa kebutuhan di masa datang

11 | http://www.jurnal.umb.ac.id/index.php/JTIS 
yang meliputi kebutuhan dalam ukuran kuantitas, kualitas, waktu dan lokasi yang dibutuhkan dalam rangka memenuhi permintaan barang ataupun jasa. Apabila metode prediksi persediaan diterapkan dalam bagian proses perencanaan produksi maka pihak perusahaan akan lebih terbantu dalam penjadwalan produksi, karena metode ini dapat memberikan output terbaik sehingga diharapkan resiko kesalahan yang disebabkan oleh kesalahan perencanaan dapat ditekan seminimal mungkin.

Pengelolaan data dan informasi merupakan bagian terpenting dalam proses pengolahan data. Data dapat didefinisikan sebagai bahan keterangan tentang kejadian-kejadian nyata atau fakta-fakta yang dirumuskan dalam sekelompok lambang tertentu yang tidak acak, yang menunjukkan jumlah, tindakan, atau hal. Data dapat berupa catatan-catatan dalam kertas, buku, atau tersimpan sebagai file dalam basis data.

Toko Bangunan Vita Viya merupakan salah satu Toko Bangunan yang terletak di Jalan Semangka Kota Bengkulu. Selama ini proses pengolahan data penjualan barang di Toko tersebut masih dilakukan secara konvensional yaitu menggunakan nota penjualan yang terjadi setiap harinya. Data nota tersebut kemudian akan dibuat pembukuan untuk mengetahui berapa banyak penjualan barang yang terjadi setiap bulannya. Pengelolaan persediaan barang juga hanya melihat sisa barang yang tersedia di Toko tanpa melihat penjualan dari barang tersebut. Permasalahan yang sering terjadi di Toko Bangunan Vita Viya yaitu pengelolaan stok barang, di mana bahan-bahan bangunan tersebut terdapat masa pemakaian sehingga tidak layak untuk dijual.

Oleh karena itu, untuk mengontrol pengelolaan persediaan barang di Toko Bangunan Vita Viya dibutuhkan suatu aplikasi yang dapat memprediksi penjualan dari barang-barang yang tersedia di Toko tersebut. Hal ini diperlukan agar dapat menjadi bayangan bagi pemilik Toko Bangunan Vita Viya berapa banyak persediaan yang harus disediakan untuk bulan berikutnya dengan melihat hasil prediksi penjualan tersebut. Salah satu metode untuk melakukan prediksi yaitu metode regresi linier. Metode regresi linier tersusun atas dasar pola hubungan data yang relevan dimasa lalu.

\section{LANDASAN TEORI}

\section{A. Metode Regresi Linear}

Analisis regresi adalah bersifat asimetri atau dua arah. Teknik regresi membuat prediksi nilai dengan nilai yang ada pada satu variabel (yang disebut variabel independen) pada variabel lain, yang disebut variabel dependen. Dalam hal ini tujuannya bukan bermaksud membuat prediksi yang sempurna. Dengan informasi pada independen bermaksud membuat prediksi nilai variabel dependen dengan error yang sekecil-kecilnya. Proposisi yang digunakan pada analisis regresi yaitu dari variabel independen $\mathrm{X}$ dan variabel dependen $\mathrm{Y}$ dinyatakan dengan regresi $\mathrm{Y}$ pada $\mathrm{X}^{1}$.

Dalam regresi, variabel yang diprediksi disebut kriterium dan variabel yang digunakan untuk memprediksi disebut prediktor. Persamaan yang menyatakan hubungan antara variabel kriterium dan variabel prediktor disebut persamaan regresi. Untuk regresi linier dengan satu prediktor, persamaannya.

\section{B. Penjualan}

Penjualan merupakan kegiatan yang berhubungan dengan keputusan-keputusan dalam Penjualan yang harus dibuat untuk menentukan produk dan pasarannya, penentuan struktur harga, dan pelaksanaan promosi serta pelaksanaan distribusi yang pada akhirnya akan memberikan kepuasan pada konsumen ${ }^{2}$.

Penjualan merupakan kegiatan yang penting dalam setiap perusahaan terutama perusahaan yang bergerak dalam bidang perdagangan. Penjualan juga merupakan urat nadi yang dapat menjaga dan memelihara kelangsungan hidup perusahaan ${ }^{3}$.

Penjualan adalah berkumpulnya seorang pembeli dan penjual dengan tujuan melaksanakan tukar menukar barang dan jasa berdasarkan pertimbangan yang berharga misalnya pertimbangan uang ${ }^{4}$.

Penjualan bila diidentifikasikan berdasarkan perusahaannya maka dapat dikategorikan menjadi beberapa jenis, yaitu :

1. Penjualan langsung di mana penjualan ini adalah dengan cara mengambil barang dari supplier kemudian secara langsung dikirim ke customer

2. Penjualan stok gudang di mana penjualan ini adalah dengan cara menjual barang dari stok yang ada di gudang.

3. Penjualan kombinasi adalah penjualan di mana dengan mengambil sebagian barang dari supplier serta sebagian dari stok yang ada di gudang.

\section{Barang}

Barang merupakan setiap benda baik yang berwujud maupun tidak berwujud. bergerak atau pun tidak bergerak. yang mempunyai banyak tujuan seperti diperdagangkan, dipakai, dipergunakan atau dimanfaatkan oleh konsumen ${ }^{5}$.

Barang merupakan benda dalam berbagai bentuk dan uraian, yang meliputi bahan baku, barang setengah jadi atau peralatan yang spesifiknya ditetapkan oleh pejabat pembuat komitmen sesuai dengan penugasan kuasa pengguna anggaran ${ }^{6}$.

\section{Microsoft Visual Studio 2010}

Microsoft Visual Basic 2010 Express adalah salah satu bagian dari Microsoft Visual Studio 2010 Express Family. Sebuah alat gratisan yang digunakan oleh pengembang windows dari berbagai level untuk mengembangkan dan membangun aplikasi yang 
bergerak di atas sistem .NET Framework, dengan menggunakan bahasa BASIC. Visual basic menyediakan cara yang cepat dan mudah untuk membuat aplikasi ${ }^{7}$.

\section{METODOLOGI PENELITIAN}

A. Sejarah Singkat Toko Bangunan Vita Viya Panorama tepatnya jalan semangka raya terdapat sebuah toko bangunan bernama Toko Bangunan Vita Viya yang dimiliki oleh Bapak Idris. Toko Vita Viya dibuka pada tahun 2007 berkisaran berdiri 9 tahun, Toko Bangunan Vita Viya awal mulanya adalah sebuah mebel yang hanya menjual kayu bulat yang masih mentah atau belum di produksi. Beberapa tahun ke depan usaha kayu Bapak Idris mulai menyusut dikarenakan stok pada kayu bulat berkurang sehingga Bapak Idris mengalihkan usahanya ke toko bangunan yang mana menjualkan berbagai alat bangunan dan di namakan toko "VITA VIYA" tepatnya di tahun 2009.

Toko Bangunan Vita Viya sebuah toko kecilkecilan pada saat itu dikarenakan barang-barang yang dijual masih terbilang sedikit dan pelanggannya belum begitu banyak, pembelian stok barang untuk memenuhi Toko Bangunan Vita Viya di beli di tempat agen-agen bangunan yang terdekat di kota bengkulu, semakin lama hasil penjualan Bapak Idris usahanya semakin berkembang walaupun untungnya masih minim. Semakin hari perkembangan usaha Bapak Idris semakin menunjukkan hasil yang baik sehingga Bapak Idris memutuskan membeli stok barang ke agen Jakarta, karena dia berpikir dengan membeli agen luar kota maka mendapatkan harga lebih murah di banding agen yang biasa dia beli sehingga membuat keuntungan lebih dari yang sebelumnya.

Barang-barang di Toko Bangunan Vita Viya sekarang sudah terbilang cukup lengkap baik dari barang material maupun non material salah satu contohnya pasir, cat tembok, semen, batu koral, keramik, Besi KSTY, dan sebagainya. Usaha Bapak Idris semakin tahun semakin maju dilihat dari toko yang besar dan barang yang lengkap, memiliki empat karyawan serta tempat toko milik pribadi. Berkat kegigihan dalam usaha sehingga toko Toko Bangunan Vita Viya Sudah terbilang toko bangunan yang besar di daerah panorama bengkulu.

B. Tempat dan Waktu Penelitian

Tempat penelitian dilaksanakan di Toko Bangunan Vita Viya di Jalan Semangka Raya Bengkulu. Waktu penelitian dimulai pada bulan Januari 2019 sampai dengan bulan Juni 2019.

1. Metode Penelitian

Metode penelitian yang diterapkan pada penelitian ini adalah dengan pengembangan metode waterfall. Metode waterfall merupakan model pengembangan sistem informasi yang sistematik dan sekuensial. Metode waterfall memiliki tahapan-tahapan

2. Perangkat Keras dan Perangkat Lunak

Perangkat keras dan perangkat lunak yang digunakan dalam penelitian ini, terlihat pada Tabel dibawah ini :

Tabel 1. Perangkat Keras dan Perangkat Lunak

\begin{tabular}{|c|c|}
\hline Perangkat Keras & Perangkat Lunak \\
\hline Laptop Lenovo & Windows 8 \\
\hline Processor & Microsoft Office \\
\hline Pentium & Visual Basic .Net \\
\hline RAM 2 GB & Balsamiq Mockup \\
\hline Hardisk 500 GB & Microsoft Visio \\
\hline
\end{tabular}

3. Metode Pengumpulan Data

Adapun metode pengumpulan data yang digunakan dalam penelitian ini, antara lain :

a) Metode Observasi

Observasi yang dilakukan yaitu penulis datang langsung ke tempat penelitian untuk mendapatkan data berupa data jumlah penjualan barang

b) Metode Wawancara

Pada tahap ini penulis melakukan wawancara dengan memberikan pertanyaan-pertanyaan yang terkait dengan masalah yang akan dibahas kepada Bapak Idris selaku Pemilik Toko Bangunan Vita Viya.

c) Studi Pustaka

Penulis mencari sumber dari buku, jurnal, karya ilmiah yang berkaitan dengan penelitian dari Perpustakaan, Internet, dan Toko Bangunan. Vita Viya.

4. Metode Perancangan Sistem

a. Analisa Sistem Aktual

Toko Bangunan Vita Viya merupakan salah satu Toko Bangunan yang terletak di Jalan Semangka Kota Bengkulu. Selama ini proses pengolahan data penjualan barang di Toko tersebut masih dilakukan secara konvensional yaitu menggunakan nota penjualan yang terjadi setiap harinya. Data nota tersebut kemudian akan dibuat pembukuan untuk mengetahui berapa banyak penjualan barang yang terjadi setiap bulannya.

b. Analisa Sistem Baru

Berdasarkan analisa sistem aktual yang telah dilakukan, maka dibutuhkan suatu aplikasi yang dapat memprediksi penjualan dari barang-barang yang tersedia di Toko Bangunan Vita Viya. 
Hal ini diperlukan agar dapat menjadi bayangan bagi pemilik Toko Bangunan Vita Viya tentang penjualan barang untuk bulan berikutnya. Dalam pembuatan aplikasi ini, penulis menggunakan bahasa pemrograman Visual Basic .Net dan membuat diagram konteks, DFD, ERD, serta rancangan input dan output.

\section{HASIL DAN PEMBAHASAN}

A. Hasil

Aplikasi dalam memprediksi data penjualan barang di Toko Bangunan Vita Viya dibuat menggunakan bahasa pemrograman Visual Basic .Net dengan menerapkan metode regresi linear. Dengan dibangunnya aplikasi dapat dijadikan sebagai alternatif dalam memprediksi data penjualan barang pada bulan berikutnya berdasarkan data penjualan yang terjadi 2 tahun terakhir yaitu dimulai dari bulan Januari 2017 sampai dengan Desember 2018. Data 2 tahun tersebut akan digunakan sebagai trend data untuk mengetahui nilai prediksi penjualan barang pada 1 tahun ke depannya.

Pada Aplikasi dalam memprediksi data penjualan barang di Toko Bangunan Vita Viya ini terdapat beberapa menu yang dapat diakses agar dapat mengelola data barang, penjualan barang serta memprediksi penjualan barang. Adapun menu yang terdapat pada aplikasi ini, antara lain :

1. Form Login

Form login merupakan antarmuka aplikasi yang pertama kali muncul ketika menjalankan aplikasi dalam memprediksi data penjualan barang di Toko Bangunan Vita Viya. Dalam form login ini terdapat otentikasi admin dengan memasukkan username dan password pada field yang telah disediakan. Pengguna yang memiliki username dan password yang benar yang dapat masuk ke menu utama untuk mengelola data pada aplikasi dalam memprediksi data penjualan barang di Toko Bangunan Vita Viya. Adapun form menu login terlihat pada gambar 1 .

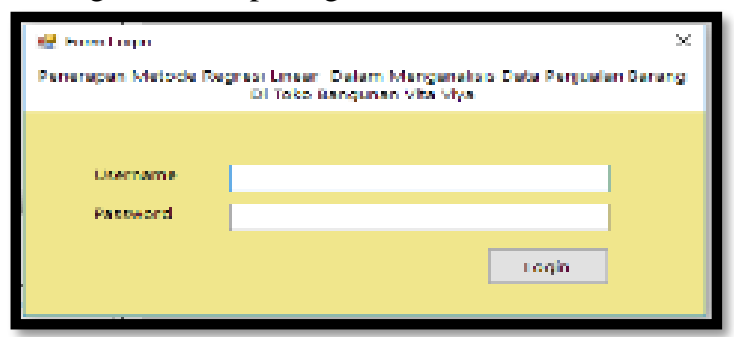

2. Menu Utama

Gbr 1 Form Menu Login

Menu utama merupakan menu yang akan muncul ketika pengguna berhasil melakukan login. Pada menu utama ini terdapat sub menu yang dapat diakses oleh pengguna, dimana masing-masing sub menu tersebut memiliki fungsi yang berbeda-beda. Adapun form menu utama pada aplikasi dalam memprediksi data penjualan barang di Toko Bangunan Vita Viya terlihat pada gambar 2 .

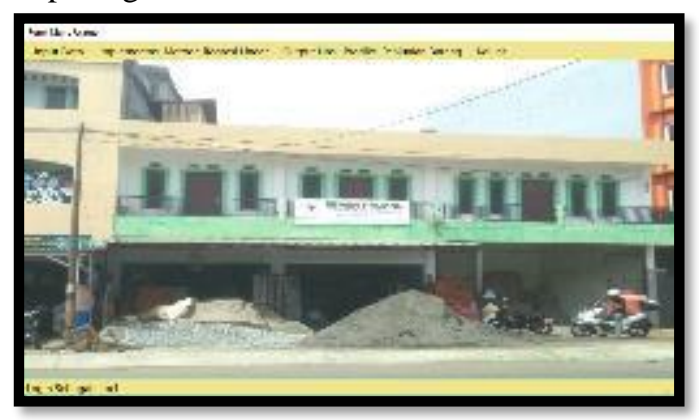

Gbr 2 Form Menu Utama

3. Sub Menu Input Data

Sub menu input data merupakan sub menu yang memiliki link untuk menampilkan form input data yang digunakan untuk proses pengolahan data agar dapat melakukan prediksi penjualan. Pada sub menu input data terdapat link untuk menampilkan form input data kategori barang, barang, dan penjualan barang seperti tampak pada gambar 3 .

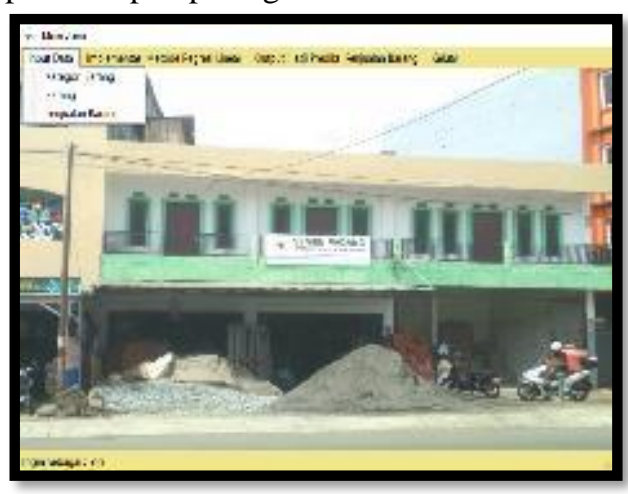

Gbr 3. Sub Menu Input Data

\section{B. Pembahasan}

Pada pembahasan ini akan dijelaskan formform input dan output yang terdapat pada aplikasi dalam memprediksi data penjualan barang di Toko Bangunan Vita Viya. Adapun form-form tersebut, antara lain :

1. Input Data Kategori

Input data kategori barang merupakan form input yang digunakan untuk mengolah data kategori barang yang terdapat di Toko Bangunan Vita Viya. Pada form input data kategori barang terdapat field yang akan diisi serta button yang digunakan untuk mengolah data mulai dari menyimpan data, mengoreksi data, serta menghapus data.. Adapun form input data kategori barang terlihat pada gambar 4 . 


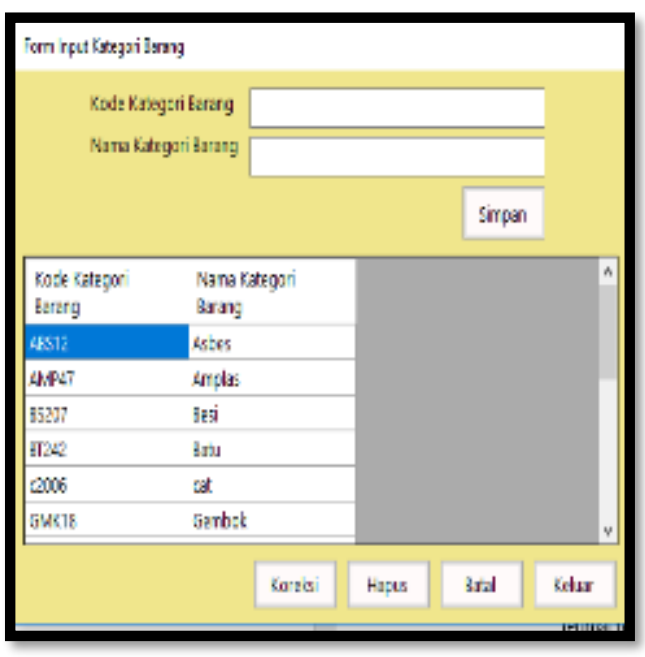

Gbr 4. Input Data Kategori Barang

2. Input Data Barang

Input data barang merupakan form input yang digunakan untuk mengolah data barang yang terdapat di Toko Bangunan Vita Viya. Pada form input data barang terdapat field yang akan diisi serta button yang digunakan untuk mengolah data mulai dari menyimpan data, mengoreksi data, serta menghapus data.. Adapun form input data barang terlihat pada gambar 5 .

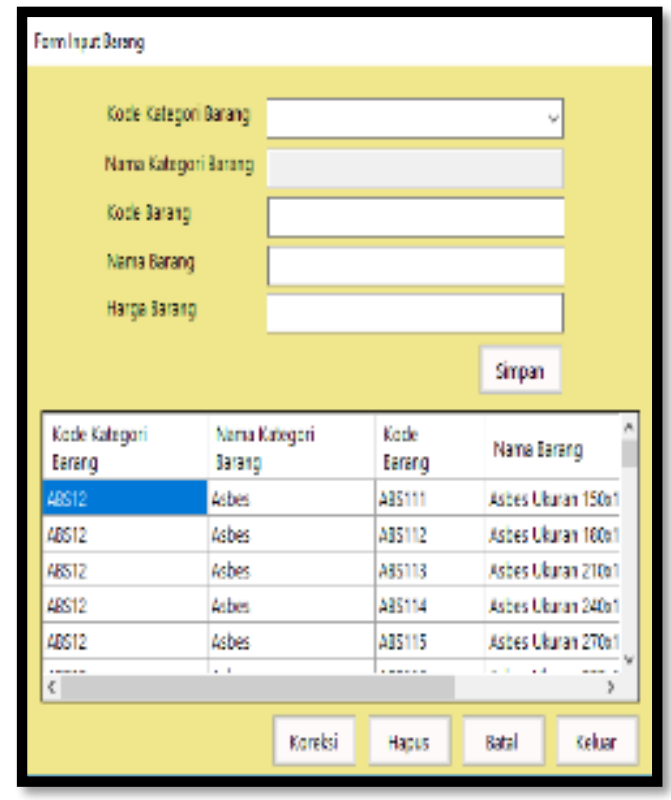

Gbr 5. Input Data Barang

3. Input Data Penjualan Barang

Input data penjualan barang merupakan form input yang digunakan untuk mengolah data penjualan yang terjadi setiap harinya berdasarkan nota transaksi. Data penjualan ini akan dijadikan sebagai master data yang akan menjadi dasar dalam melakukan prediksi penjualan barang untuk bulan berikutnya. Pada form input data barang terdapat field yang akan diisi serta button yang digunakan untuk mengolah data mulai dari menyimpan data, mengoreksi data, serta menghapus data. Adapun form input data penjualan barang terlihat pada gambar 6 .

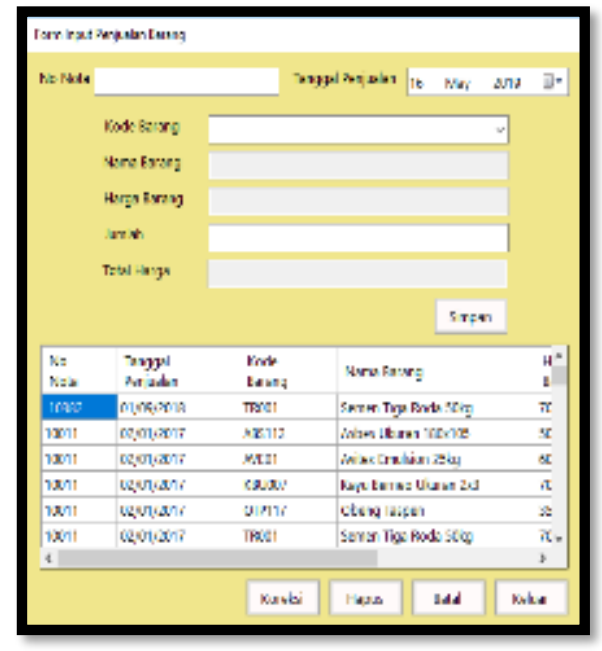

Gbr 6. Input Data Penjualan Barang

4. Form Implementasi Metode Regresi Linear Merupakan form yang digunakan untuk mengimplementasi metode regresi linear pada data penjualan barang yang telah diinput sebelumnya agar dapat memprediksi penjualan barang pada bulan berikutnya dalam kurun waktu 1 tahun ke depan. Adapun form implementasi metode regresi linear seperti Gambar 7.

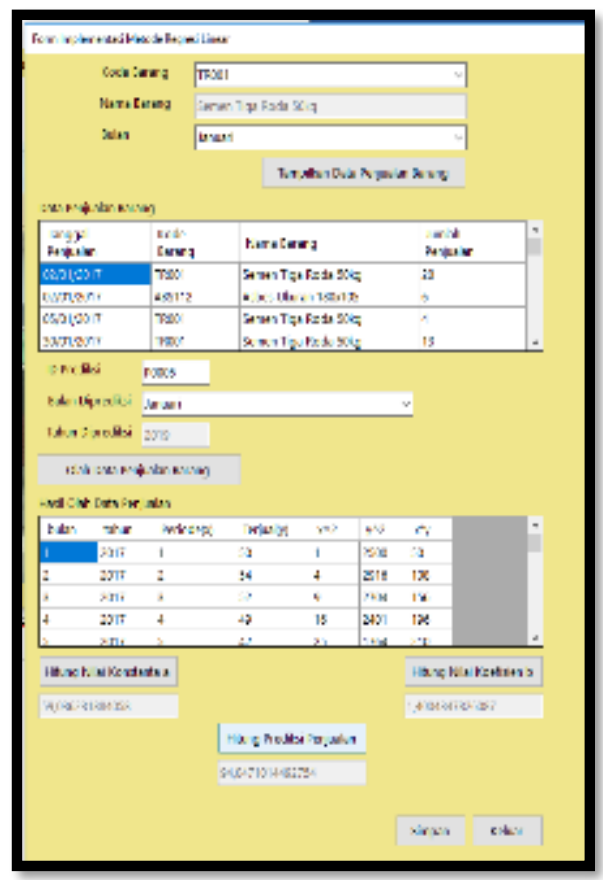

Gbr 7. Form Implementasi Metode Regresi Linear

5. Output Hasil Prediksi Penjualan Barang

Merupakan output yang menampilkan informasi hasil prediksi penjualan per bulan prediksi, dan juga grafik pada masing-masing barang dalam kurun waktu 2 tahun penjualan barang. Adapun output hasil prediksi penjualan barang terlihat pada Gambar 8.

15 | http://www.jurnal.umb.ac.id/index.php/JTIS 


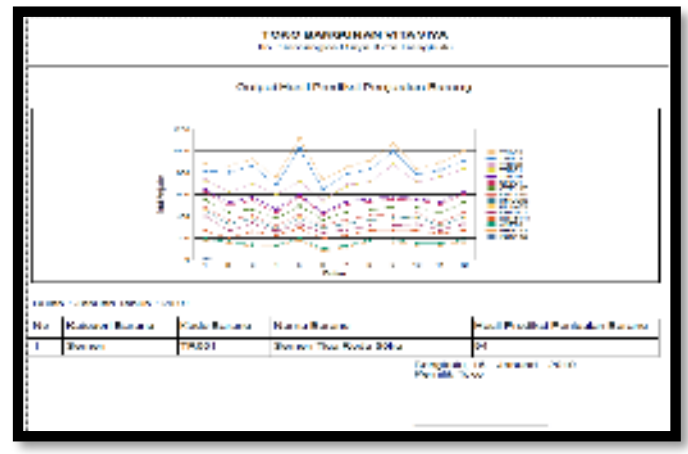

Gbr 8. Output Hasil Prediksi Penjualan Barang

C. Hasil Pengujian Sistem

Pengujian sistem dilakukan dengan menggunakan metode black box, yaitu dengan menguji form input data yang terdapat pada Aplikasi dalam memprediksi data penjualan barang di Toko Bangunan Vita Viya, antara lain :

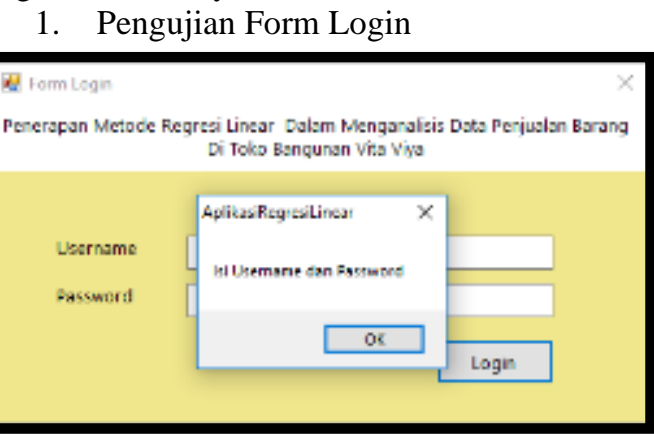

Gbr 9. Pengujian Form Login (Username dan Password Kosong)

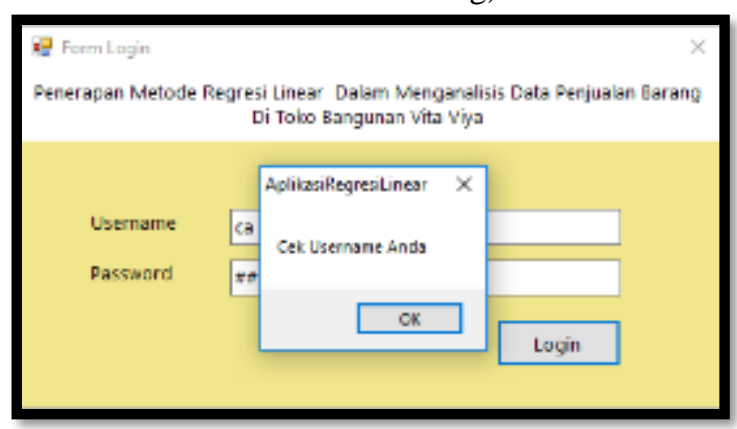

Gbr 10. Pengujian Form Login (Username Salah)

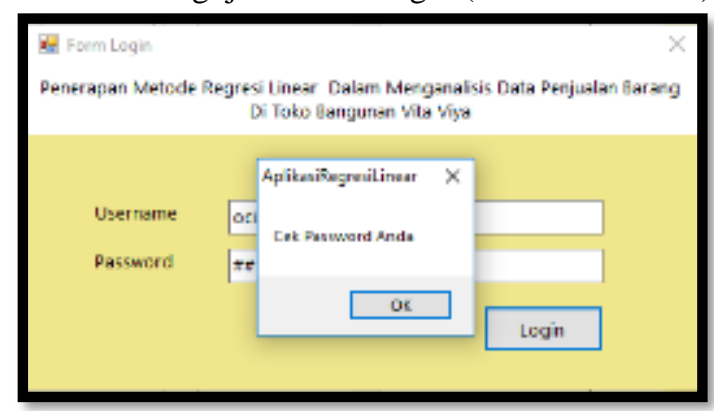

Gbr 11. Pengujian Form Login (Password Salah)

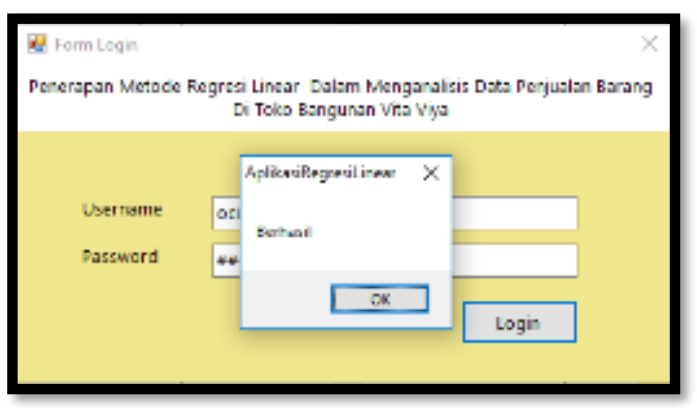

Gbr 12. Pengujian Form Login (Username dan Password Benar)

2. Form Implementasi Metode Regresi Linear

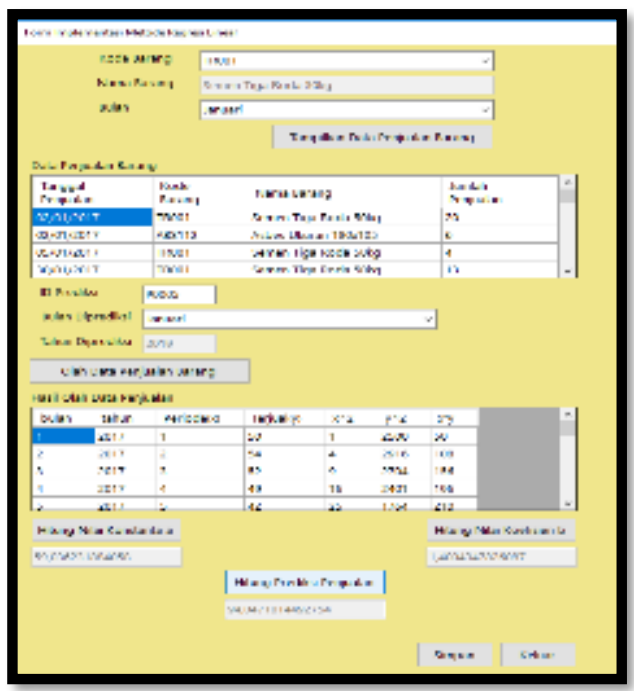

Gbr 13. Pengujian Form Prediksi Bulan Januari 2019

Adapun hasil pengujian yang dilakukan pada Aplikasi dalam memprediksi data penjualan barang di Toko Bangunan Vita Viya, seperti terlihat pada tabel 1 .

Tabel 1. Hasil Pengujian Sistem

\begin{tabular}{|l|l|l|l|l|}
\hline No & Form & \multicolumn{1}{|c|}{$\begin{array}{c}\text { Skenario } \\
\text { Pengujian }\end{array}$} & $\begin{array}{l}\text { Hasil Yang } \\
\text { Diharapkan }\end{array}$ & Hasil Pengujian \\
\hline 1 & Login & $\begin{array}{l}\text { Memasukkan } \\
\text { username atau } \\
\text { password yang } \\
\text { salah }\end{array}$ & $\begin{array}{l}\text { Sistem } \\
\text { menolak } \\
\text { akses login }\end{array}$ & $\begin{array}{l}\text { Sistem berhasil } \\
\text { menolak akses } \\
\text { tersebut dengan } \\
\text { menampilkan } \\
\text { pesan }\end{array}$ \\
\hline 2 & Login & $\begin{array}{l}\text { Memasukkan dan } \\
\text { username dang } \\
\text { password yang } \\
\text { benar }\end{array}$ & $\begin{array}{l}\text { Sistem } \\
\text { menerima } \\
\text { akses login }\end{array}$ & $\begin{array}{l}\text { Sistem berhasil } \\
\text { menerima akses } \\
\text { login dan } \\
\text { menampilkan } \\
\text { menu utama } \\
\text { secara otomatis }\end{array}$ \\
\hline 4 & $\begin{array}{l}\text { Form } \\
\text { Imple } \\
\text { mentas } \\
\text { i } \\
\text { Metode } \\
\text { Regresi } \\
\text { Linear }\end{array}$ & $\begin{array}{l}\text { Memilih barang } \\
\text { ban bulan yang } \\
\text { akan diprediksi }\end{array}$ & $\begin{array}{l}\text { Sistem } \\
\text { berhasil } \\
\text { melakukan } \\
\text { proses } \\
\text { prediksi } \\
\text { dengan } \\
\text { menunjukkan } \\
\text { hasil prediksi } \\
\text { pada bulan } \\
\text { tertentu }\end{array}$ & $\begin{array}{l}\text { Sistem berhasil } \\
\text { memprediksi } \\
\text { penjualan barang }\end{array}$ \\
\end{tabular}

16 | http://www.jurnal.umb.ac.id/index.php/JTIS 
Berdasarkan pengujian yang telah dilakukan, dapat ditarik kesimpulan bahwa Aplikasi mampu memprediksi penjualan barang untuk 1 tahun ke depan berdasarkan data penjualan yang telah diinputkan sebelumnya.

Selain itu pengujian juga dilakukan terhadap nilai prediksi yang didapatkan dari metode regresi linear, menggunakan metode MAPE (Mean Absolute Presetage Error) dan MSE (Mean Square Error). Tujuan dari pengujian ini yaitu untuk mengetahui nilai error dari hasil nilai prediksi yang didapatkan dari metode regresi linear.

Adapun Rumus MAPE seperti :

$$
M A P E=\frac{\sum_{t=1}^{n} \frac{\left|Y_{t}-Y^{\prime}{ }_{t}\right|}{Y_{t}}}{n}
$$

Adapun Rumus MSE seperti :

Di mana :

$$
M S E=\frac{\sum_{t=i}^{n}\left(Y_{t}-Y^{\prime}{ }_{t}\right)}{n}
$$

$Y^{\prime}{ }_{t}=$ nilai prediksi penjualan

$Y_{t}=$ nilai real penjualan

$n$ = banyaknya data

Sampel Data yang digunakan adalah Semen Tiga Roda 50kg. Berdasarkan hasil prediksi dari bulan Januari sampai dengan April 2019, didapatkan nilai prediksi, seperti Tabel 4.2.

Tabel 2. Nilai Prediksi Penjualan Semen Tiga Roda 50kg dari Bulan Januari sampai dengan April 2019

\begin{tabular}{|c|c|}
\hline Bulan & Nilai Prediksi \\
\hline Januari & 94 \\
\hline Februari & 95 \\
\hline Maret & 96 \\
\hline April & 98 \\
\hline
\end{tabular}

Setelah mendapatkan data real dari tempat penelitian, didapatkan nilai real penjualan dari bulan Januari sampai dengan April 2019, seperti Tabel 3.

Tabel 3. Nilai Real Penjualan Semen Tiga Roda 50kg dari Bulan Januari sampai dengan April 2019

\begin{tabular}{|c|c|}
\hline Bulan & Nilai Real Penjualan \\
\hline Januari & 98 \\
\hline Februari & 117 \\
\hline Maret & 105 \\
\hline April & 120 \\
\hline
\end{tabular}

Setelah didapatkan nilai real dan nilai prediksi, maka akan dilakukan pengujian menggunakan 2 metode yaitu MAPE, dan MSE.

1. Pengujian MAPE

$$
M A P E=\frac{\sum_{t=1}^{n} \frac{\left|Y_{t}-Y^{\prime}{ }_{t}\right|}{Y_{t}}}{n}
$$

$$
\begin{aligned}
& M A P E \\
& =\frac{\left(\frac{98-94}{98}\right)+\left(\frac{117-95}{117}\right)+\left(\frac{105-96}{105}\right)+\left(\frac{120-98}{120}\right)}{4} 0,0857+0,1833 \\
& M A P E=\frac{0,0408+0,18803+0,43}{4} \\
& M A P E=\frac{0,49783}{4} \\
& \text { 2. Pengujian MSE }=0,1244575 \\
& M S E=\frac{\sum_{t=i}^{n}\left(Y_{t}-Y^{\prime}{ }_{t}\right)}{n} \\
& \begin{array}{c}
M S E \quad 98-94)+(117-95)+(105-96)+(120-98) \\
4
\end{array} \\
& M S E=\frac{4+22+9+22}{4} \\
& M S E=\frac{57}{4} \\
& M S E=14,25
\end{aligned}
$$

Berdasarkan kedua pengujian tersebut, didapatkan kesimpulan bahwa nilai error dari hasil nilai prediksi yang didapatkan dari metode regresi linear menggunakan metode MAPE sebesar 0,1244575 . Sedangkan menggunakan metode MSE sebesar 14,25 .

\section{Penutup}

A. Kesimpulan Berdasarkan hasil dan pembahasan serta hasil pengujian, maka dapat disimpulkan bahwa :

1. Aplikasi dalam memprediksi data penjualan barang di Toko Bangunan Vita Viya dibuat menggunakan bahasa pemrograman Visual Basic .Net dengan menerapkan metode regresi linear. Dengan dibangunnya aplikasi dapat dijadikan sebagai alternatif dalam memprediksi data penjualan barang pada bulan berikutnya berdasarkan data penjualan yang terjadi 2 tahun terakhir yaitu dimulai dari bulan Januari 2017 sampai dengan Desember 2018. Data 2 tahun tersebut akan digunakan sebagai trend data untuk mengetahui nilai prediksi penjualan barang pada 1 tahun ke depannya.

2. Berdasarkan pengujian yang telah dilakukan, dapat ditarik kesimpulan bahwa Aplikasi mampu memprediksi penjualan barang untuk 1 tahun ke depan berdasarkan data penjualan yang telah diinputkan sebelumnya.

3. Berdasarkan pengujian nilai error menggunakan metode MAPE dan MSE, didapatkan hasil bahwa nilai error dari hasil nilai prediksi yang didapatkan dari metode regresi linear menggunakan metode MAPE sebesar 0,1244575 . Sedangkan menggunakan metode MSE sebesar 14,25.

B. Saran 
Berdasarkan kesimpulan, maka penulis menyarankan untuk mempergunakan aplikasi ini agar mendapatkan informasi hasil prediksi penjualan barang berdasarkan data penjualan barang yang telah terjadi sebelumnya dengan nilai error yang lebih kecil.

\section{Referensi}

[1] Sumanto. 2014. Statistika Deskriptif. Penerbit CAPS (Center Of Academic Publishing Service) : Yogyakarta.

[2] Fitriani, Uci. Dkk. 2016. Pengaruh Sistem Penjualan Kredit Di PT. Surya Putera Sumatera Raya II Pasir Putih Pasir Pengaraian Terhadap Penarikan Sepeda Motor Yamaha. Artikel Ilmiah Progra Studi Manajemen Fakultas Ekonomi Universitas Pasir Pengaraian.

[3] Iskandar, Agus. Rangkuti, Haris. 2008. Perancangan Sistem Informasi Penjualan Tunai Pada PT. Klaten Bercahaya. Jurnal Basis Data ICT Research Center UNAS Vol.3 No.2 November 2008 ISSN:1978:9483.

[4] Anthony. Dkk. 2017. Analisis dan Perancangan Sistem Informasi Penjualan Berdasarkan Stok Gudang Berbasis Client Server (Studi Kasus Toko Grosir Restu Anda). Jurnal Teknologi Informasi dan Ilmu Komputer (JTIIK) Vol.4 No.2 Juni 2017 ISSN:2355-7699.

[5] Wibowo, Heri Prasetyo. Sismoro, Heri. 2012. Analisis dan Perancangan Sistem Informasi Penjualan Barang Dan Jasa Pada CV. Wijaya Teknik Yogyakarta Berbasis Web. Jurnal DASI Vol.13 No.3 September 2012 ISSN:1411-3201.

[6] Aswan. 2012. Kumpulan Program Kreatif Dengan Visual Basic .NET. Penerbit Informatika : Bandung.

[7] Saputro, Adiyanto. 2014. Sistem Pendukung Keputusan Penentuan Jumlah Pengadaan Barang Pada CV. Roda Baja Mandiri Semarang Dengan Metode Mamdani. Laporan Tugas Akhir Universitas Dian Nuswantoro Semarang. 